\title{
EVOLUTION OF SUSTAINABLE WATER RESOURCES INDICATORS
}

\author{
Ethan T. Smith ${ }^{*}$ and Harry X. Zhang ${ }^{* *}$ \\ * Coordinator, Sustainable Water Resources Roundtable, c/o U.S. Geological Survey, \\ Reston, VA 20192 \\ ** Principal Technologist, CH2M Hill, 15010 Conference Center Drive, Chantilly, VA \\ 20151
}

\begin{abstract}
The Sustainable Water Resources Roundtable (SWRR) is one of several natural resource roundtables with government, corporate, and NGO participation. SWRR has been a subgroup of the Advisory Committee on Water Information (ACWI) since 2001, and operates under authority of OMB M-92-01 and the Federal Advisory Committee Act. The purpose of the Roundtable is to provide an open forum for exchanging ideas and information to foster collaboration on ways to manage water resources in such a way that the resource and its uses may be sustained over the long term.

Earlier three papers in this series described work leading up to the completion of the 2005 Preliminary Report. The present paper continues the idea that water indicators will have to evolve over many years to really become accepted for public policy making. Some of the most important topics that do not appear in the 2005 Preliminary Report are shown here. The intent is to illustrate how gaps in the indicator series might be filled, and how additional indicators may be needed to complete a short list of key national water indicators.

The journey toward Sustainable Water Resources Management begins by determining the most important water issues and indicators. Sustainable Water Resources Roundtable participants are committed to interdisciplinary, inter-jurisdictional, and cross-ownership collaboration that identifies and supports national, state, and field-level activities to sustain water resources. The long-term goals of SWRR include the development of principles, criteria and indicators to support decision-making and identification of opportunities for collaboration on research needs.
\end{abstract}

\section{KEYWORDS}

Sustainable development, water sustainability, indicator, water resources, water quality, sustainable water resources management, Sustainable Water Resources Roundtable 


\section{INTRODUCTION}

The Sustainable Water Resources Roundtable (SWRR) is one of several natural resource roundtables with government, corporate, and NGO participation while others deal with forestry, rangelands, and minerals. SWRR has been a subgroup of the Advisory Committee on Water Information (ACWI) since 2001, and operates under authority of OMB M-92-01 and the Federal Advisory Committee Act. As one of the milestones for this collaborative effort, the Preliminary Report was completed by SWRR in 2005 and is available at http://acwi.gov/swrr/.

The purpose of the Roundtable is to provide an open forum for exchanging ideas and information to foster collaboration on ways to manage water resources in such a way that the resource and its uses may be sustained over the long term. Roundtable discussions and activities will focus in part on criteria, indicators, and methods for assessing the sustainability of water resources, as well as exploring and improving how this information is used to promote sustainable water resource management.

Earlier three papers in this series at WEFTEC (Smith and Zhang, 2004a; 2005; 2006) and two related papers at Water Environment \& Technology (Smith and Zhang, 2004; 2007) described work leading up to the completion of the 2005 Preliminary Report. The first paper in this publication series entitled "Formulating Key Water Quality Indicators for Sustainable Water Resources Development" at WEFTEC'04 emphasizes the application of the water sustainability framework to the water quality field. The objective of the second paper, "Part II: Scale Issues and Geographic Patterns", which was presented at WEFTEC'05, is to address the importance of scale issues and geographic patterns and how they may influence the formulation of key water sustainability indicators. The third paper, “Our Journey Towards Sustainable Water Resources Management: Preliminary Report by the Sustainable Water Resources Roundtable," was presented at WEFTEC'06. It is a summary of the 2005 report which describes 17 indicators currently proposed as a way to characterize water sustainability. The paper also contrasts the 17 indicators with a possible short list of key water indicators that might be used for policy making.

The present paper continues the idea that water indicators will have to evolve over many years to really become accepted for public policy making. Some of the most important topics that do not appear in the 2005 Preliminary Report are shown here. The intent is to illustrate how gaps in the indicator series might be filled, and how additional indicators may be needed to complete a short list of key national water indicators.

\section{METHODOLOGY}

There are certain conceptual foundations that have been developed to aid in understanding sustainability. SWRR recognizes the importance of the 1987 Brundtland Commission definition, which relies on maintaining equity between generations to help define terms. Beyond this, however, SWRR embraces systems analytic concepts to 
sharpen the definition. For example, the Brundtland definition assumes that future generations will need the same mix and share of resources that we enjoy. This may not be so if technology changes to require less of $\mathrm{X}$ and more of $\mathrm{Y}$ than we use at present.

Water sustainability solutions are characterized by certain systems analysis properties that may indicate the overall stability of the system. It is important for sustainability that solutions to problems should be viable for long durations; that the system should not be required to undergo extreme change in short periods of time to reach the desired solution; that the solution sought is often a compromise of available options, and not some extreme case; and, is not overly complex. Even with these precautions, the most successful solutions often possess the additional property of reversibility. Only actual experience can tell us if we are on the right track and if not we must be able to make changes. Whether the geographic scale is a local water problem or a national system, these rules tend to produce sustainable solutions.

One can imagine far more concepts than can be captured as indicators. Some are quantitative, but others qualitative and not readily measured. We are therefore faced with choosing some limited number of indicators; too many will overwhelm the policy making process, and may paralyze decision making. Too few will fail to describe issues in sufficiently comprehensive manner. There is no single set of criteria for what makes a good indicator. Our current short list of key national water indicators is admittedly just one possible set. It has the advantage of being smaller than the list of 17 indicators used in the 2005 Preliminary Report.

\section{RESULTS AND DISCUSSION}

\section{Setting the Context for Water Resources}

A fundamental consideration is how the whole water resources discipline relates to society in general, when we claim to be concerned about sustainability. Earlier papers have examined the properties of a sustainable (or stable) system, but is there any short way to obtain an intuitive feeling for what this means? As it turns out, there are some aides that may help us to do this. Figure 1 is a diagram showing how social, economic, and environmental elements might interact to produce a region of sustainability. While it is easy to draw Venn diagrams, and we might debate what the intersections really mean, still this is a useful way to recognize that water sustainability is not simply a matter of achieving a clean environment, or of having enough funding to produce some desirable result. For example, the cultural elements can become extremely important when one realizes that the whole undertaking about how to use water resources is clearly different in various nations around the world. Not all would subscribe to the same balance that has been adopted in the West, although we seldom realize this fact. 


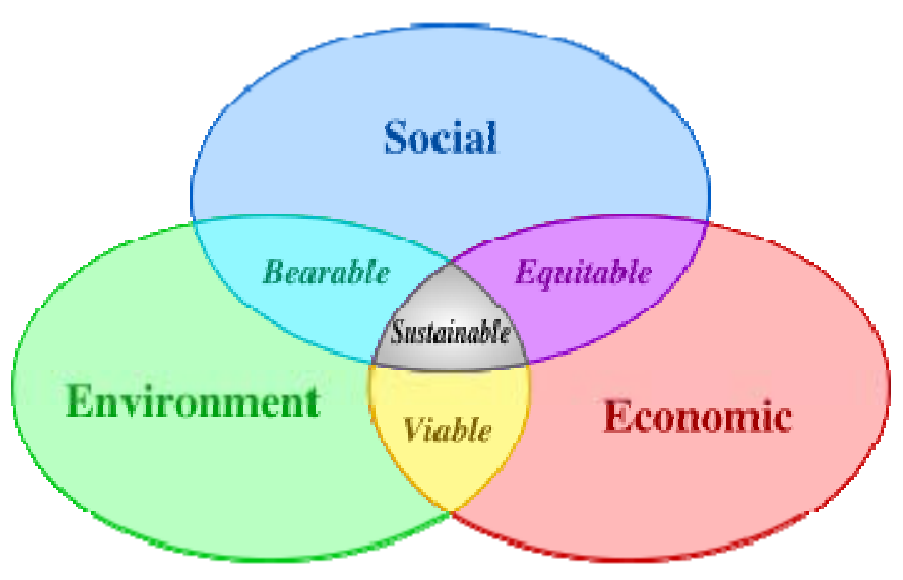

Figure 1 - Diagram of Sustainable Development

(Source: Wikipedia, the free encyclopedia (2007). "Sustainable Development", http://en.wikipedia.org/wiki/Sustainable_development)

Another short way to look at the place of water resources in the grand scheme of things is also from Wikipedia. The short way to describe sustainability requires that human activity, at a minimum, only uses nature's resources at a rate at which they can be replenished naturally. Wikipedia (2007) points out that one can describe sustainability in a short table, as follows:

Table 1 - Wikipedia's Definitions of Sustainability

\begin{tabular}{|l|l|l|}
\hline \multicolumn{1}{|c|}{$\begin{array}{c}\text { Consumption of } \\
\text { renewable resources }\end{array}$} & \multicolumn{1}{|c|}{ State of environment } & \multicolumn{1}{c|}{ Sustainability } \\
\hline $\begin{array}{l}\text { More than nature's ability to } \\
\text { replenish }\end{array}$ & Environmental degradation & Not sustainable \\
\hline $\begin{array}{l}\text { Equal to nature's ability to } \\
\text { replenish }\end{array}$ & Environmental equilibrium & Steady-state Sustainability \\
\hline $\begin{array}{l}\text { Less than nature's ability to } \\
\text { replenish }\end{array}$ & Environmental renewal & Sustainable development \\
\hline
\end{tabular}

We may argue that these definitions seem obvious, but they help provide the basis for what we seek to do in this paper, which is establish a set of water indicators that may help policy makers to draw better conclusions about exactly this kind of situation. Therefore, the purpose of this section is really to provide a useful starting point for seeking better ways to define indicators that can evolve as our knowledge increases. 


\section{Public Policy Issues as Driving Forces}

In earlier papers we have alluded to the fact that the choice of indicator is influenced, if not mandated, by the kind of public policy issue that is being faced by a policy maker. There are some obvious examples. One might imagine that the mayor of a city is concerned about the local water supply afforded by the river running through the town. Similarly, a state governor has quite different concerns if he is trying to protect a regional aquifer from contamination because it is important for water supply. Then too, a U.S. senator may be called upon to help craft legislation about irrigation policy that will affect the entire nation. These people have very different needs, and therefore require different water indicators to help them.

But so far in this series we have not really tried to define exactly what these public policy issues might be, except for examples like the one above. Bearing in mind that our entire project has always been strongly slanted toward the national level, we have now made a first attempt to list at least what seem to be the most important of these public policy issues. Our first attempt is as follows, although at the outset we make no claims that it is complete, always correct, or that it may not change as we learn more.

\section{Issue Definitions for Water Resources Sustainability}

\section{Water Availability}

1. Depletion of ground water and water-level decline:

Even under present conditions, continued pumping of ground water could lead to falling water tables and depletion of aquifers. Difficult tradeoffs may be necessary among current uses, and between present and future uses.

2. Further development of ground water and recharge rates:

Further development pressure for additional use of ground water seems likely, because of growth in some areas of the country, because of uncertain rules for orderly ground-water development, and simply because it is there. But recharge rates for aquifers are fixed, and some way must be found to accommodate growth without destroying the resource.

3. Transfer or leasing of water rights to the highest bidder and impact of recent court decisions on water markets:

Water rights doctrine may be changing radically -- whether prior appropriation or riparian rights are now in effect -- to reflect new concepts treating water as a marketable good. For example, a farmer may lease water rights to a utility because it is the highest bidder. The courts are wrestling with how to balance the equities of water transfer.

4. Recycling and reuse of wastewater:

The increasing competition for water resources could lead to the recycling of wastewater and reusing it for various purposes. Questions arise about where users stand in the 
pecking order of use, and who pays how much for what. Also, at what point does water become sufficiently scarce to warrant such measures, and who decides the way scarcity is determined, for example, the market or the government.

5. Interstate or inter-basin transfer of water to water-scarce areas, and allocation and diversion of surface water:

The transfer of water from one region to another across watershed boundaries or State borders such as allocation of Colorado River water -- both actually and legally -- is a thorny example. Issues may arise because of differing growth in water rich and water poor regions, because of long continued historic uses, because of State or Federal involvement in attempting to allocate water, and for many other reasons.

6. Allocation of ground water among various users:

Issues about how to allocate ground water may be expected to arise because of the competition caused by possible aquifer depletion, the need to accommodate new users, and pressure to develop the resource. The allocation mechanism might be some mixture of water markets, State or Federal water use permits, court battles, etc.

7. Competing uses for instream and offstream purposes and hydrologic modifications due to dams and reservoirs:

Competitions exist among instream uses (such as recreation, fisheries, and hydropower) and offstream uses that require water to be withdrawn in order to meet some demand. Issues may arise because of the need to maintain instream flows, because of regional growth and development, because natural water systems must be modified to accommodate some types of use, and because of conflicts among instream purposes (perhaps fish versus some other purpose).

\section{Water Quality}

8. Thermal pollution of surface water due to industrial discharges:

Pollution can be caused by the dissipation of heat from power plants to surface waters. For example, the thermal discharges from coal-fired or nuclear electric power generating facilities, after once-through cooling, to the receiving waters. Issues may originate because of conflicts between the need for energy and water-quality standards, because of the cost of alternatives like air cooling (and who pays for it), and beneficial vs. harmful effects of heat in the stream.

9. Point and nonpoint sources from municipal and industrial treatment plants, stormwater systems, nonpoint sources:

Control of wastewater from point sources like municipal / industrial treatment plants depends on achieving technology that can in fact meet the increasingly stringent standards for effluents, and this too in the face of growth of raw waste input to the plants. Regional systems have economies of scale, but also very large point loadings. Nonpoint source control is even harder, since one must first "capture" the waste. Issues may arise 
because the effluent loadings cannot really be controlled by available technology, because the costs become very great, and because of conflicts between growth as the cause of wastewater and simultaneously as the source of tax base to pay for its control.

10. Impact of toxics, pesticides, other agricultural wastes, and radioactives on surface and ground water:

Toxic and hazardous substances are of increasing concern, and may include industrial chemicals, agricultural wastes (not all are toxic, but there are pesticides, herbicides, and insecticides), and radioactive wastes (from both repositories and in wastewater). Materials may be discharged into surface waters, pumped into the ground, and/or infiltrate into aquifers. Issues may arise because of conflicts between the danger of these substances and their great value to the economy, because of the long-term nature of some types of contamination, and because of the cost of control (and who pays).

11. Escalating costs due to stricter environmental laws:

Costs of meeting regulations set by every level of government are increasing, because of more stringent environmental standards, because of a greater amount of waste generated by the system, and because of more complex wastes. Other increased costs are for structures (e.g., to protect from spills), and for bringing good quality water to the user. Benefits are tricky to estimate, but include improved recreation, fisheries, and avoiding costs that would be caused by abated pollution (e.g., medical costs). Issues include how to determine appropriate benefit/cost tradeoffs, and the distribution of costs and benefits among for instance income levels of the population, and sectors of the economy (who pays, who benefits).

12. Surface-water impacts from sedimentation, acid precipitation, acid mine drainage, eutrophication and all water-quality stressors: Impacts on surface water (except for toxics, see above) are measured by any of the usual parameters of water quality such as BOD, DO, $\mathrm{pH}$, nitrates etc. Special problems include acid precipitation, acid mine drainage, and eutrophication. Issues may arise because of conflicts between enhanced water quality and the need for economic growth, because of conflict about how much waste the environment can safely assimilate, because of uncertain causes (in the case of acid precipitation), because of the inability to find a responsible party (in the case of abandoned mines), and because of complex interactions between manmade causes and natural phenomena (in the case of eutrophication).

13. Ground-water impacts from salinity or aquifer contamination measured by any water-quality parameter:

Impacts on ground water (except for Toxics, see above) are measured by any of the usual water quality parameters such as inorganic materials, minerals, metals, microbial contaminants, synthetic organic chemicals (e.g., gasoline). Issues may arise from tradeoffs between using the ground for a source of water versus disposal of waste, from conflicts about salt water intrusion resulting from overuse, and from the difficulty of connecting cause with effect because of the "hidden" nature of ground water and the lengthy time periods involved for movement. The boundary between this issue area and the toxics area is fuzzy. 


\section{Hazards and Land Use}

14. Impact of drought on water availability:

Periodic water shortages or longer term cyclic droughts put stress on water supplies, especially if they are already fully developed. Issues may center on difficult tradeoffs among different uses of scarce water, on how to carry out mitigation of drought impact (e.g., seeking new supplies, conserve, regulate, differential pricing), or on immediate versus long-term benefits.

15. Impact of floods and potential mitigation:

Periodic floods account for great damage, especially in developed areas subject to recurring problems (like flood plains). Issues may concern the amount of effort that should be expended (dams, other structures) to control floods, the pros and cons of continued building in the flood plain, the distribution of costs of mitigation vs. who benefits, and the appropriate role of government in such natural disasters.

16. Impact of soil erosion, land subsidence, sinkholes and soil salinity on land use: Effects like erosion and soil salinity greatly impact agricultural lands. Subsidence and sinkholes, as well as water-triggered landslides, affect developed land uses. Agricultural issues may include who should do what, who pays for it, and what regulation should exist. Land use issues may concern where development should be allowed, what kind of mitigation should be carried out, and possible conflict between government regulation and private land ownership.

17. Climate impact, "greenhouse" effect on rising sea levels and geographic changes in hydrologic cycle:

Climate changes may include rising sea levels and storm damage in coastal areas, possibly due to atmospheric carbon dioxide and other gases. Changing climate patterns may alter precipitation, thus affecting agriculture positively in some regions, and negatively in others. Other water supplies would be affected too. Issues may concern to what extent these changes will occur, over what time periods, and what sorts of impacts will occur where. If climate changes happen, tradeoffs may center on what action should be taken by whom, and the cost of action now vs. the benefit of avoiding long-term problems.

Note that the numbering is only for convenience in working with this list of public policy issues, and does not imply priority. This is certainly a lengthy list, and probably includes most if not all of the water issues that are likely to occur. Remembering that we are for now working mostly at a national geographic scale, the problem becomes how to develop water indicators that relate to these driving issues that will also be useful to public policy makers. 


\section{Developing Water Resources Relationships}

Figure 2 was developed to help focus on how many disparate elements of water resources might be related. As one moves along the time path from one point to the next, we have tried to depict at least some major interrelationships that involve water and the rest of the physical-economic-cultural system. This flowchart may not be complete, and indeed other such depictions might be created. Some of the pathways shown can be quantified, but certainly not all of them. This figure does however convey the complexity of the system we are trying to describe, how hard it will be to maintain sustainable conditions over time, and why we believe it will take many years to really understand the system.

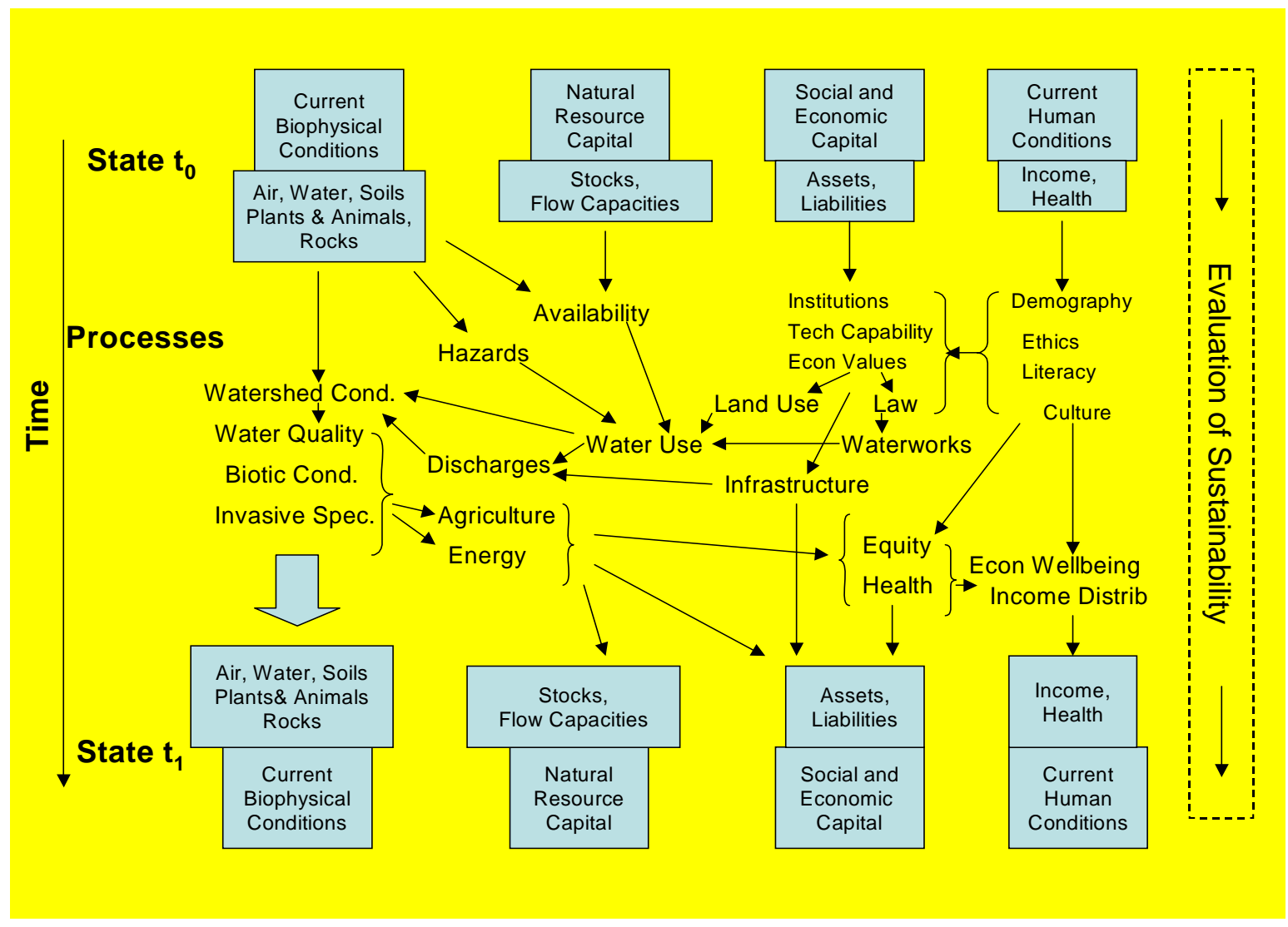

Figure 2 - Water resources in the physical-economic-cultural system (SWRR, 2005)

The figure shows far more concepts than can be captured as indicators. Some are quantitative, but others qualitative and not readily measured. We are therefore faced with choosing some limited number of indicators; too many will overwhelm the policy making process, and may paralyze decision making. Too few will fail to describe issues in sufficiently comprehensive manner. There is no single set of criteria for what makes a good indicator, although we have suggested a simple checklist used by GAO (2004). 


\section{An 8-Indicator Framework}

Now we have postulated the driving forces that describe water issues at the national level, and tried to place in a general context the relationships among possible forces that influence water resources. In a previous paper we have formulated an 8 indicator framework based on these ideas, and compared it to the results of the 2005 report done by the Sustainable Water Resources Roundtable (available at http://acwi.gov/swrr/).

At this point we can reformulate our 8 indicator framework, and show how it can be populated with indicator statistics. This process will form the remainder of this paper.

Table 2 - 8-Indicator Framework

\begin{tabular}{|c|c|c|}
\hline Sample Indicators & Significance & $\begin{array}{l}\text { Selected Data } \\
\text { Period }\end{array}$ \\
\hline \multicolumn{3}{|c|}{ Water Quality Indicators } \\
\hline $\begin{array}{l}\text { Oil Spills in U.S. Water } \\
\text { - Number and Volume } \\
\text { (Coast Guard) }\end{array}$ & $\begin{array}{l}\text { This highly visible indicator commonly shows } \\
\text { major problems. }\end{array}$ & 1973 to 2001 \\
\hline $\begin{array}{l}\text { Emerging Contaminants } \\
\text { (USGS) }\end{array}$ & $\begin{array}{l}\text { Emerging contaminants are newer chemicals } \\
\text { and more exotic materials that are not really } \\
\text { addressed by present programs. }\end{array}$ & 1999 to 2002 \\
\hline $\begin{array}{l}\text { Contaminated Sediments } \\
\text { (EPA) }\end{array}$ & $\begin{array}{l}\text { Substances that contaminate sediments can } \\
\text { remain for many years and continue to impact } \\
\text { the ambient water and ecosystem. Remediation } \\
\text { is difficult and expensive. }\end{array}$ & $\begin{array}{l}1980 \text { to } 1993 \\
\text { updated to } \\
2004\end{array}$ \\
\hline \multicolumn{3}{|c|}{ Water Quantity Indicators } \\
\hline $\begin{array}{l}\text { U.S. Climate Extremes } \\
\text { Index (NOAA) }\end{array}$ & $\begin{array}{l}\text { The trends for precipitation are shown, which } \\
\text { may be related to climate change. }\end{array}$ & 1910 to 2005 \\
\hline $\begin{array}{l}\text { Water Consumption and } \\
\text { Availability (USGS) }\end{array}$ & $\begin{array}{l}\text { The water budget for the nation shows the ratio } \\
\text { of consumptive use to renewable supply by } \\
\text { geographic region. }\end{array}$ & 1995 \\
\hline \multicolumn{3}{|c|}{ Water Use Indicators } \\
\hline $\begin{array}{l}\text { U.S. Water Withdrawals } \\
\text { by End Use (USGS) }\end{array}$ & $\begin{array}{l}\text { This set of indicators shows what components } \\
\text { of society withdraws water according to } \\
\text { amount. Geographic trends can be examined. }\end{array}$ & $\begin{array}{l}1950 \text { to } 2000 \\
\text { (every } 5 \text { years) }\end{array}$ \\
\hline \multicolumn{3}{|c|}{ Landscape Indicators } \\
\hline $\begin{array}{l}\text { Aquatic species at risk } \\
\text { (EPA from The Nature } \\
\text { Conservancy) }\end{array}$ & $\begin{array}{l}\text { Geographic patterns are shown of species at risk } \\
\text { by number of species. }\end{array}$ & 1996 \\
\hline $\begin{array}{l}\text { Agricultural Runoff for } \\
\text { Soil, Pesticides, and } \\
\text { Nitrogen (USDA- } \\
\text { NRCS) }\end{array}$ & $\begin{array}{l}\text { Receiving water may be impacted by runoff due } \\
\text { to pesticide, nitrogen, and sediment } \\
\text { constituents. This important effect illustrates a } \\
\text { link between agriculture and water quality via } \\
\text { land use. }\end{array}$ & 1990 to 1995 \\
\hline
\end{tabular}




\section{(1) Oil Spills in U.S. Waters}

Figure 3 shows oil spills that have been tracked by the Coast Guard for many years. At least for the statistics given here, the picture shows an encouraging trend. There have been no spills over one million gallons between 1991 and 2001. The enormous impact of oil spills on water quality and aquatic ecology imply that this indicator would be important for inclusion in any set used for policy making.

This indicator has not appeared before, either in the 2005 report of the Roundtable or in previous papers. One important aspect of this indicator is that it focuses attention on offshore areas, whereas other indicators tend to focus on inland surface or ground water. Yet, we know that coastal and estuarine systems are very important parts of the aquatic ecology, and are unusually vulnerable to oil spills because of shipping.

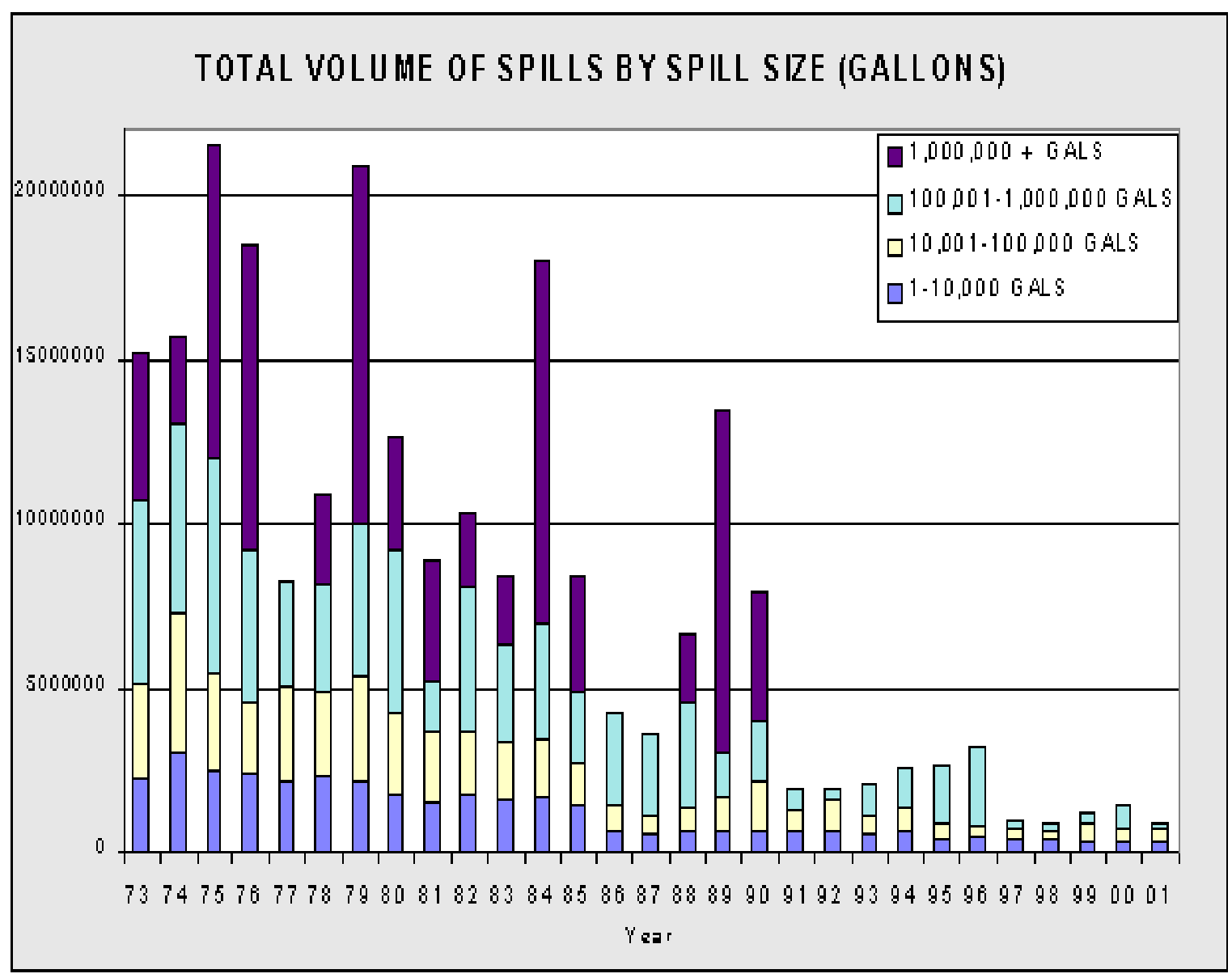

Figure 3 - Total Volume of Oil Spills by Spill Size

(Source: Compliance Analysis Division, U.S. Coast Guard, Polluting Incident Compendium, 1973-2001; http://www.uscg.mil/hq/g-m/nmc/response/stats/Summary.htm) 
The statistics show a complex picture about oil spills. About $29 \%$ of this volume during the period 1991 to 2001 were in rivers and canals, so the indicator does in fact have some inland coverage. Also, 53.7\% of the number of spills from 1991 - 2001 occurred from non-tank vessels; $18.7 \%$ were not traced; $22.1 \%$ were from facilities and other nonvessels; 5.06\% were from tank vessels (ships/barges); and .5\% were from pipelines. Taken together, it seems that this indicator offers reasonable coverage for tracking oil spills nationwide.

It is easy to visualize seabirds and other creatures coated with spilled oil. Yet, not all spills are of this kind. About 19.8\% of the number of spills from 1991 - 2001 involved the discharge of crude oil or heavy oil; 30.0\% involved intermediate fuel oils; $44.5 \%$ involved other petroleum products; and $4.9 \%$ involved gasoline products. Non-petroleum products, such as vegetable oils and wood creosotes, accounted for .8\% of the spills.

\section{(2) Emerging Contaminants}

Figure 4 shows emerging contaminants that have been monitored by the USGS between 1999 and 2002. In some publications these chemicals or those like them may be called by other names, e.g., compounds of emerging concern. This is the indicator we have chosen to use for ambient water quality, in place of the usual suite of conventional pollutants that are more familiar. There are specific reasons for this choice.

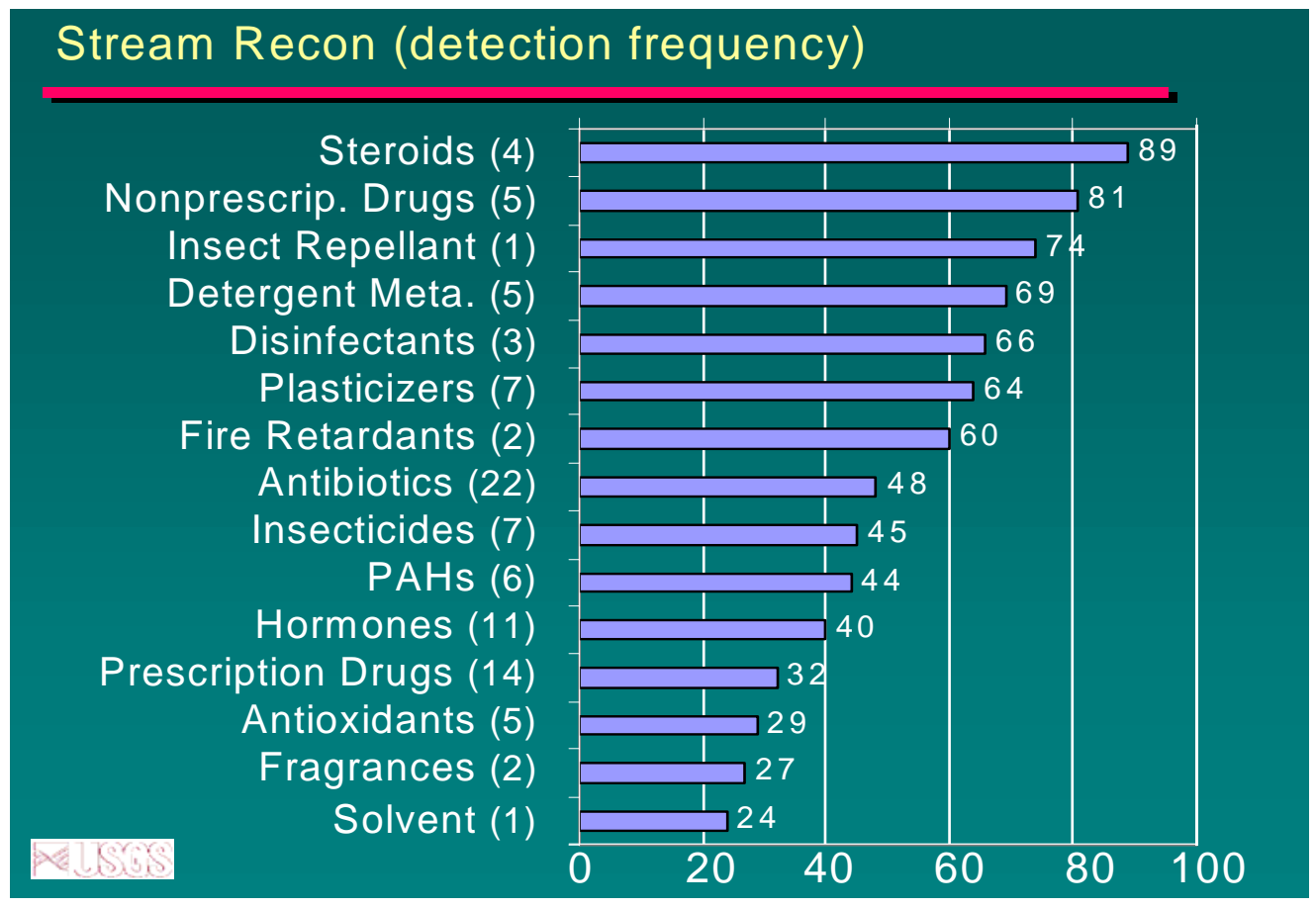

Figure 4 - Emerging Contaminants (Source: USGS Toxic Substances Hydrology Program, http://toxics.usgs.gov/regional/emc.html) 
Most important is the fact that these are exactly the contaminants that are most poorly addressed by today's programs, and thus most likely to occur in future public policy issues. Technology advances over time, and we must look to developing future programs to address such changes. Second, we are familiar with the long list of water quality parameters that are typically measured, and it is very difficult to see how to represent all these parameters in some acceptable water quality index; this has been tried by EPA, but never really gained acceptance. The survey of impaired waters under 305(b) also leaves much to be desired, although the details about this survey are beyond the scope of this paper.

Therefore, emerging contaminants, which is an indicator not before displayed either in the 2005 report or this series of papers, has been selected. To be sure, this is a moving target, and the statistics reported by USGS may be expected to change as we learn more. The present statistics have measured 158 compounds in water, and 83 compounds in sediment. Those occurring in water include 45 antibiotics, 20 drugs, 14 hormones and steroids, and 79 household and industrial chemicals. The USGS National Reconnaissance Studies effort covered streams, ground water, sources of drinking water, and streambed sediment.

Some general conclusions can be reached from the work so far accomplished. Detections and concentrations are generally higher in surface water than ground water; the concentrations of mixtures are generally low; and most targeted compounds are not detected alone. The USGS has reported on this work in Environmental Science and Technology, March 13, 2002. An important property of environmental contaminants is that both wastewater and water treatment plants vary in their ability to reduce the chemicals. Since the plants were not designed for this purpose, this should come as no surprise. This will be a future, and no doubt costly, challenge we must face.

Our ability to measure contaminants currently exceeds our understanding of their environmental effects. We know there is a danger of contaminant uptake, and possible concentration up the food chain. There is anecdotal evidence of endocrine disruption locally in some species, but tracking exact causes is difficult. Antibiotic resistance may be expected, for the same reasons that overuse of medical antibiotics can lead to resistant strains of harmful bacteria. Linked to that problem is the likely occurrence of pathogens as the end result of the process. It is not hard to see a number of public policy issues emerging from this topic in the coming years, which of course means we need an indicator to track it.

\section{(3) Contaminated Sediments}

Figure 5 shows the national map of contaminated sediments as measured by EPA. This is a new indicator that has not appeared before either in the 2005 report or in this series of papers. It is included because of the unique importance of certain chemicals that can collect in bottom sediments, and at elevated levels they can affect bottom-dwelling organisms. Pollutants in sediments can also accumulate in aquatic organisms and move 
up the food chain to fish, shellfish and eventually to humans. Thus, contaminated sediments constitute a concealed reservoir of potentially harmful materials that must be considered in assessing the ambient environment.

In 2004 EPA released a report to Congress on the "Incidence and Severity of Sediment Contamination in Surface Waters of the United States, National Sediment Quality Survey, Second Edition.” This report identifies areas in the United States where the sediment may be contaminated at potentially harmful levels. The report also assesses changes in sediment contamination over time for areas in the United States where we have enough data.

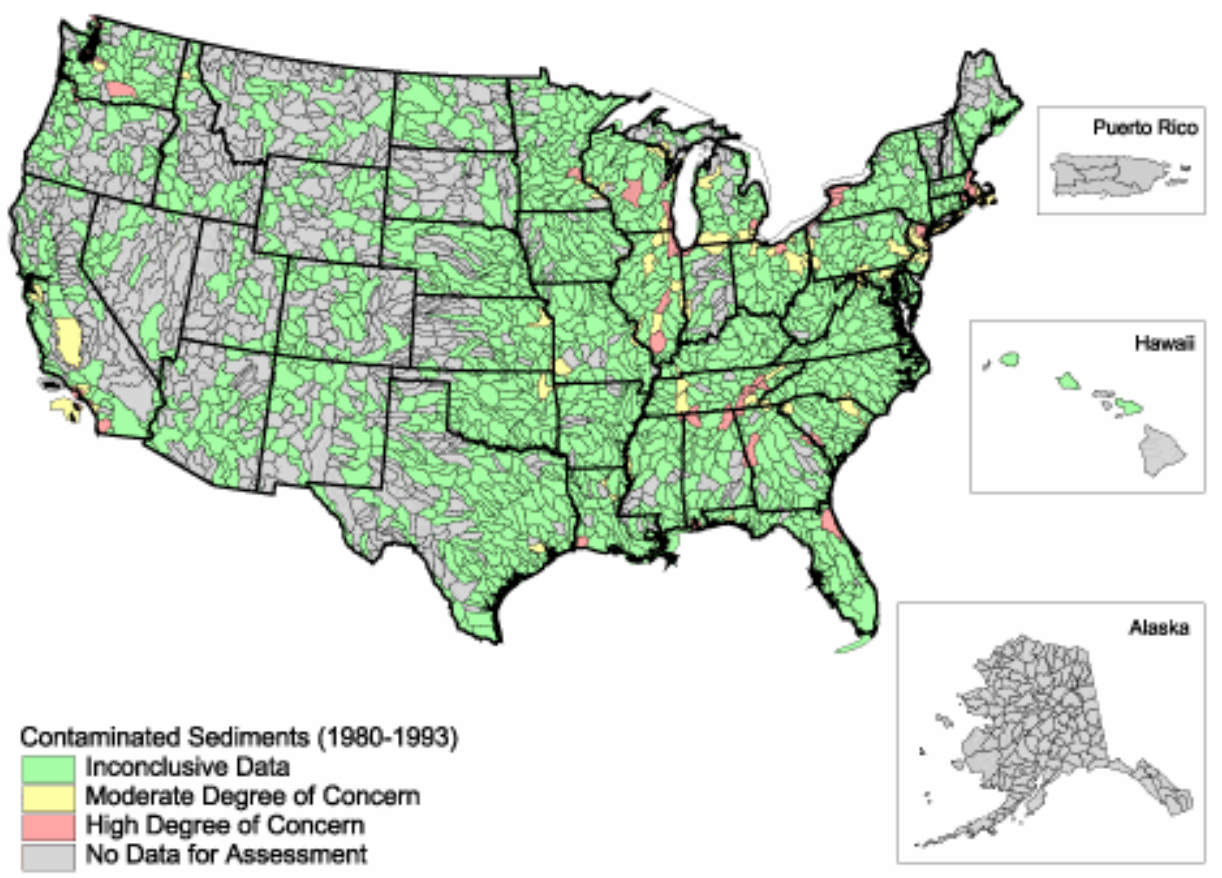

Figure 5 - Contaminated Sediments between 1980 and 1993. (Source: National Sediment Quality Survey Database, http://www.epa.gov/waterscience/cs/report/2004/)

EPA evaluated sediment contaminant data at 19,398 sampling stations nationwide. Of these stations, they believe that 8,348 or $43 \%$ are probably associated with harmful effects on aquatic life or human health. Also, 5,846 stations or 30\% are possibly associated with harmful effects on aquatic life or human health. And finally, 5,204 or $27 \%$ have no indication of associated harmful effects. The report identifies 96 watersheds where a higher proportion of sediments are contaminated at a level of concern for harmful effects. EPA evaluation of historical sediment data from 1980 through 1999 tended to show either a decrease or no change in sediment contamination in most regions where data were available. 
The limitations of the evaluation approach include uncertainties in the tools used to assess sediment quality. Because of these limitations, this draft report assesses only those locations in the U.S. where exposure to contaminated sediments is likely to cause negative effects to human health and the environment. Since the data in this report come from non-random sampling and do not cover the entire country, it is not appropriate to use them to create a national estimate of contaminated sediments. Neither should results from the trend assessment be extrapolated to areas of the country where we did not have data. The picture that emerges is one of serious but localized pollution that affects discrete rivers and streams; the fact that little change is detected may imply that the sediments will continue to constitute a largely unmitigated source of future pollution.

\section{(4) U.S. Climate Extremes Index}

Precipitation extremes (Figure 6) are important for understanding the inputs to the entire hydrologic system. Obviously, if the water available in the whole system were to greatly diminish, all other aspects of policy related to water would have to take this into consideration. The National Oceanic and Atmospheric Administration (NOAA) has attempted to characterize how the climate has changed over the past 50 or more years. One tool to aid in the development of a framework for quantifying observed changes in climate is the U.S. Climate Extremes Index (CEI). The figure shows the sum of (a) percentage of the U.S. with a much greater than normal number of days with precipitation, and (b) the percentage of the U.S. with a much greater than normal number of days without precipitation. Although this is only one step of the NOAA model, it yields a way to grasp long-term trends as an indicator. This is an indicator that does not appear in either the 2005 report or in a previous paper in this series.

How has the climate changed over the past 50 or more years? In what ways and by how much? Many people, including climatologists, have been struggling with these questions for some time now, not only for scientific interest, but also to aid in policy decisions (IPCC, 2001 and 2007) and to inform the general public. In order to answer these questions, it is important to obtain comprehensive and intuitive information which allows interested parties to understand the scientific basis for confidence, or lack thereof, in the present understanding of the climate system. One tool, first developed as a framework for quantifying observed changes in climate within the contiguous Unites States, is the U.S. Climate Extremes Index (CEI).

The CEI was first introduced in early 1996 (Karl et al., 1996) with the goal of summarizing and presenting a complex set of multivariate and multidimensional climate changes in the United States so that the results could be easily understood and used in policy decisions made by non-specialists in the field. The contiguous U.S. was selected as the focus for this study in part since climate change is of great interest to U.S. citizens and policy makers and since climate changes within the U.S. have not been given extensive coverage in intergovernmental or national reports which focus on climate change assessments (IPCC, 2001). 


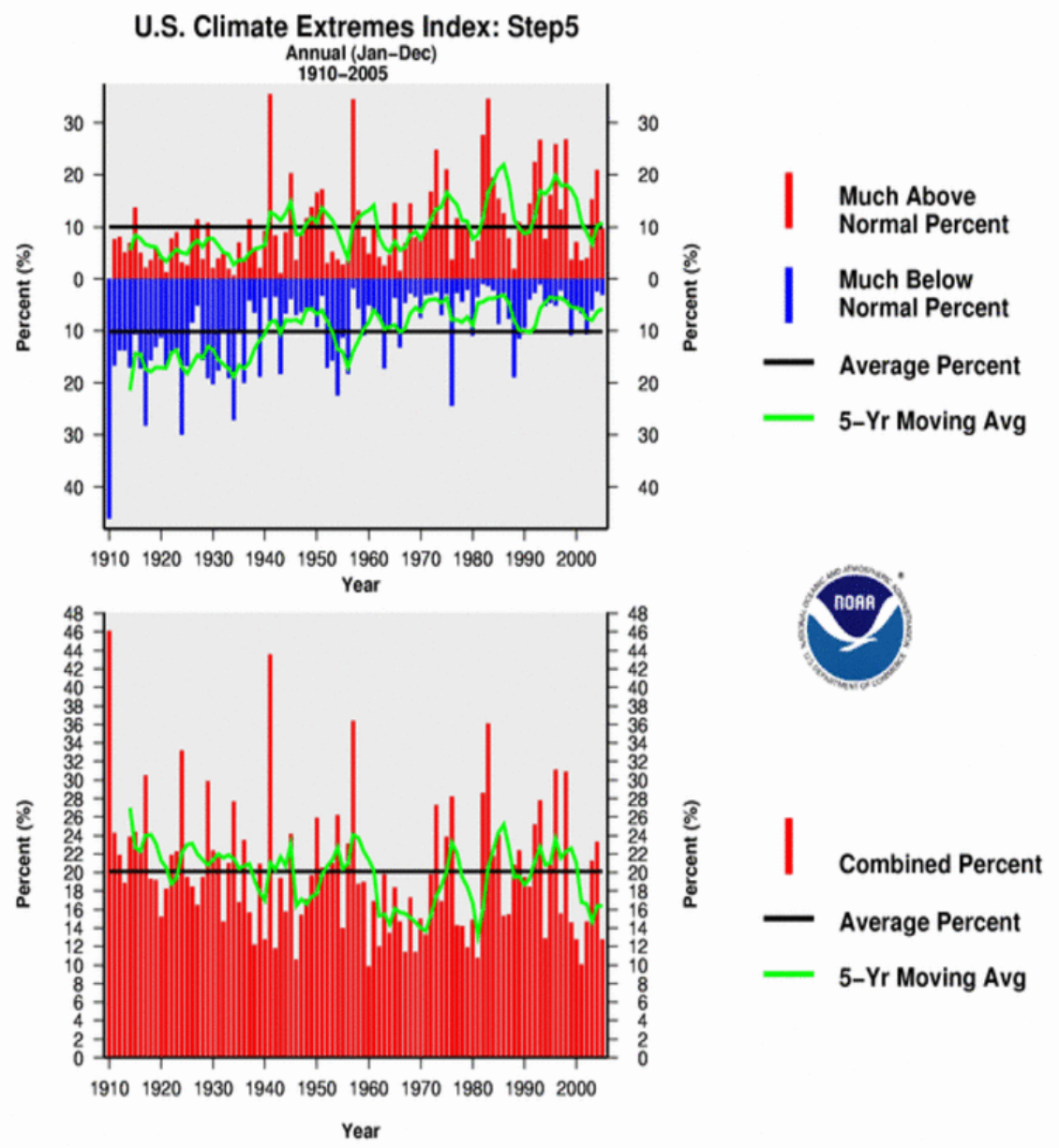

Figure 6 - U.S. Climate Extremes Index

(Source: NOAA Satellite and Information Service, National Environmental Satellite, Data, and Information Service (NESDIS), National Climatic Data Center, U.S. Department of Commerce. http://www.ncdc.noaa.gov/oa/climate/research/cei/cei.html)

\section{(5) Water Consumption and Availability}

Figure 7 shows the national and regional map for water consumption and renewable supply. This indicator combines aspects of the 2005 SWRR indicators on Gross Water Availability, Total Withdrawals for Human Use, and Water Use Sustainability. One reason for preferring this indicator is the existence of the USGS, which has the mission to continue and update the statistics. Although some data can be collected as part of the water use program, a thorough assessment of renewable supply is technically challenging and time-consuming. Determining the availability of water in the nation is essential, but it is not easy. 
The renewable water supply is the sum of precipitation and imports of water, minus the water not available for use through natural evapotranspiration and exports. Renewable water supply is a simplified upper limit to the amount of water consumption that could occur in a region on a sustained basis. Requirements to maintain minimum flows in streams leaving the region for navigation, hydropower, fish, and other instream uses limit the amount of the renewable supply available for use. Also, total development of a surface-water supply is never possible because of increasing evaporative losses as more reservoirs are used. Nevertheless, the renewable supply compared to consumptive use is an index of the degree to which the resource has already been developed.

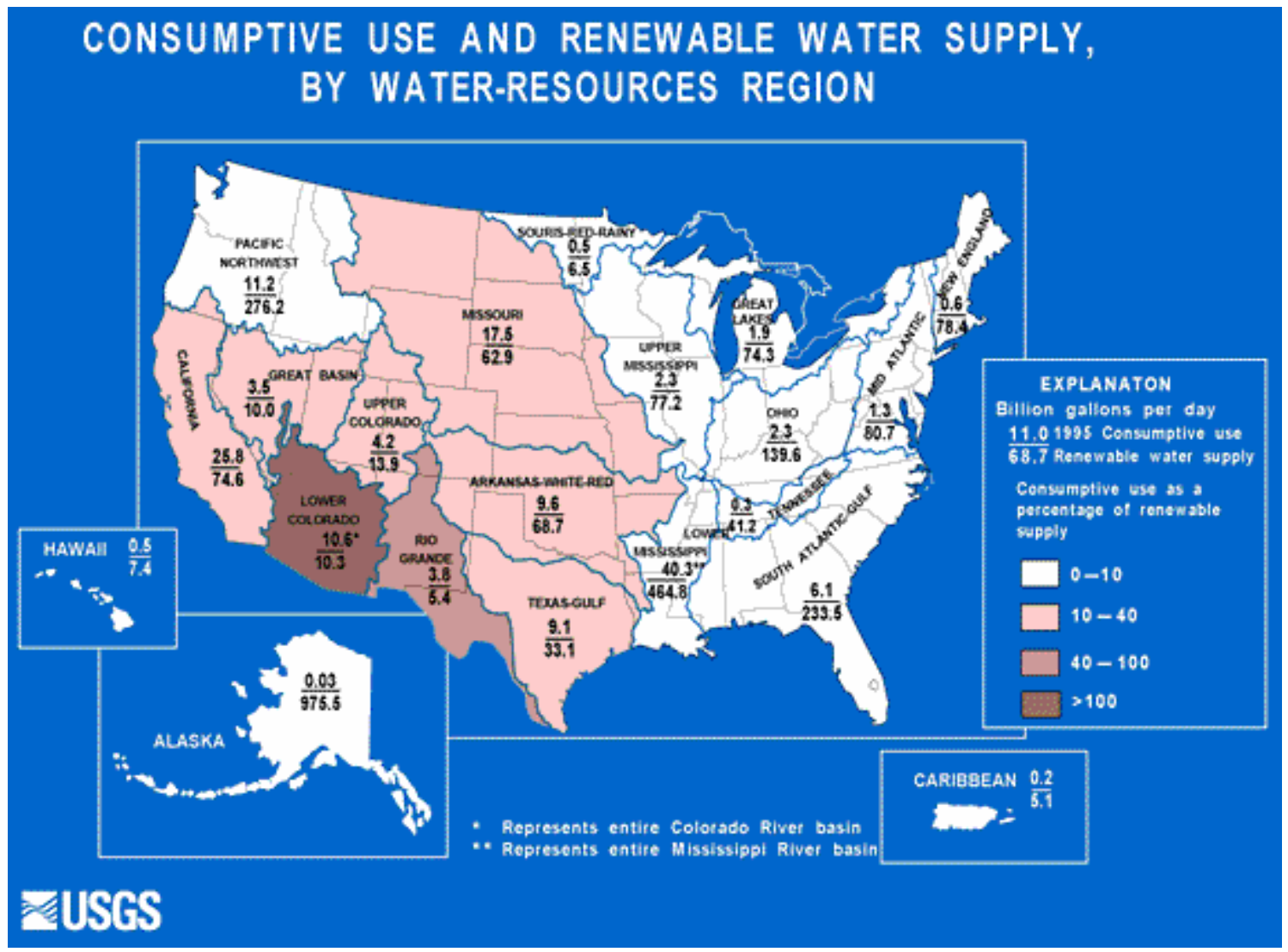

Figure 7 - Consumptive Use and Renewable Water Supply, 1995

(Source: http://water.usgs.gov/watuse/misc/consuse-renewable.html)

\section{(6) U.S. Water Withdrawals by End Use}

Figures 8, 9, and 10 show the complex of water use indicators. These statistics have been used extensively in the 2005 report and elsewhere. The USGS program is definitive for this topic. Water-use indicators are measurements of the amounts of water withdrawn from the ground or diverted from a surface-water source for offstream uses in homes, businesses, industries, and on farms. Offstream water uses are reported by source (surface 
water or ground water), by type (fresh or saline water), and by sector (public supply, domestic, and so forth). Water-use indicators also include measurements of instream uses for hydroelectric power, transportation, recreation, and assimilation of wastewater.

It is useful to show water-withdrawal and water-use measurements spatially, such as by State (Figure 8). It is also useful to show graphical trends in water use over time (Figures 9 and 10).

Indicators

- Indicator 1: Total water withdrawals for all uses in the United States. This indicator is the total of all water withdrawals for all uses in the United States, and includes both fresh and saline water withdrawals from surface waters and ground waters. The U.S. Geological Survey (USGS) collects water-use information from across the country and publishes the data every 5 years (Hutson et al., 2004). Total water withdrawals in the United States in 2000 were 408 billion gallons per day. These withdrawals consist of fresh and saline water withdrawals for eight categories of water use-public supply, domestic, irrigation, livestock, aquaculture, industrial, mining, and thermoelectric. The four largest withdrawal categories have been public supply, industrial, irrigation, and thermoelectric power. In 2000, these categories represented 98 percent of total withdrawals (public supply, 11 percent; industrial, 5 percent; irrigation, 34 percent; and thermoelectric-power, 48 percent). The data are reported by States as shown in Figure 8 (Hutson et al., 2004) and counties (see http://water.usgs.gov/).

- Indicator 2: Withdrawals by source-surface water and ground water. Knowledge of the source of water withdrawn is important for understanding which components of the hydrologic system are being stressed. Currently, the USGS reports the overall source of water withdrawals-surface water or ground water-but does not report the specific source of each withdrawal (that is, river, reservoir, aquifer, and so forth). In 2000, total surface-water and ground-water withdrawals were 323 billion gallons per day and 84.5 billion gallons per day, respectively. 

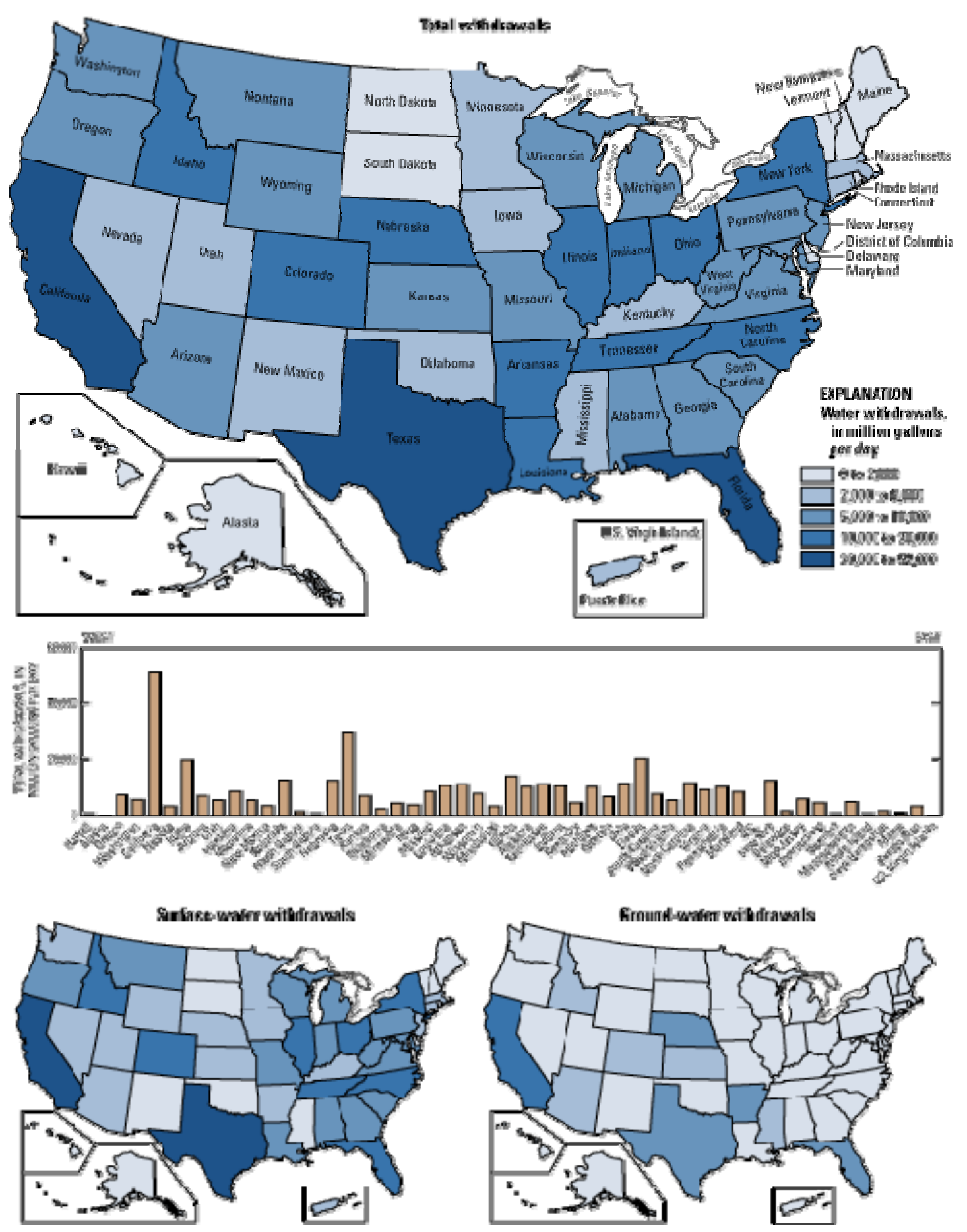

Figure 8 - Total, surface-water, and ground-water withdrawals for the United States, 2000 (Hutson et al., 2004) 


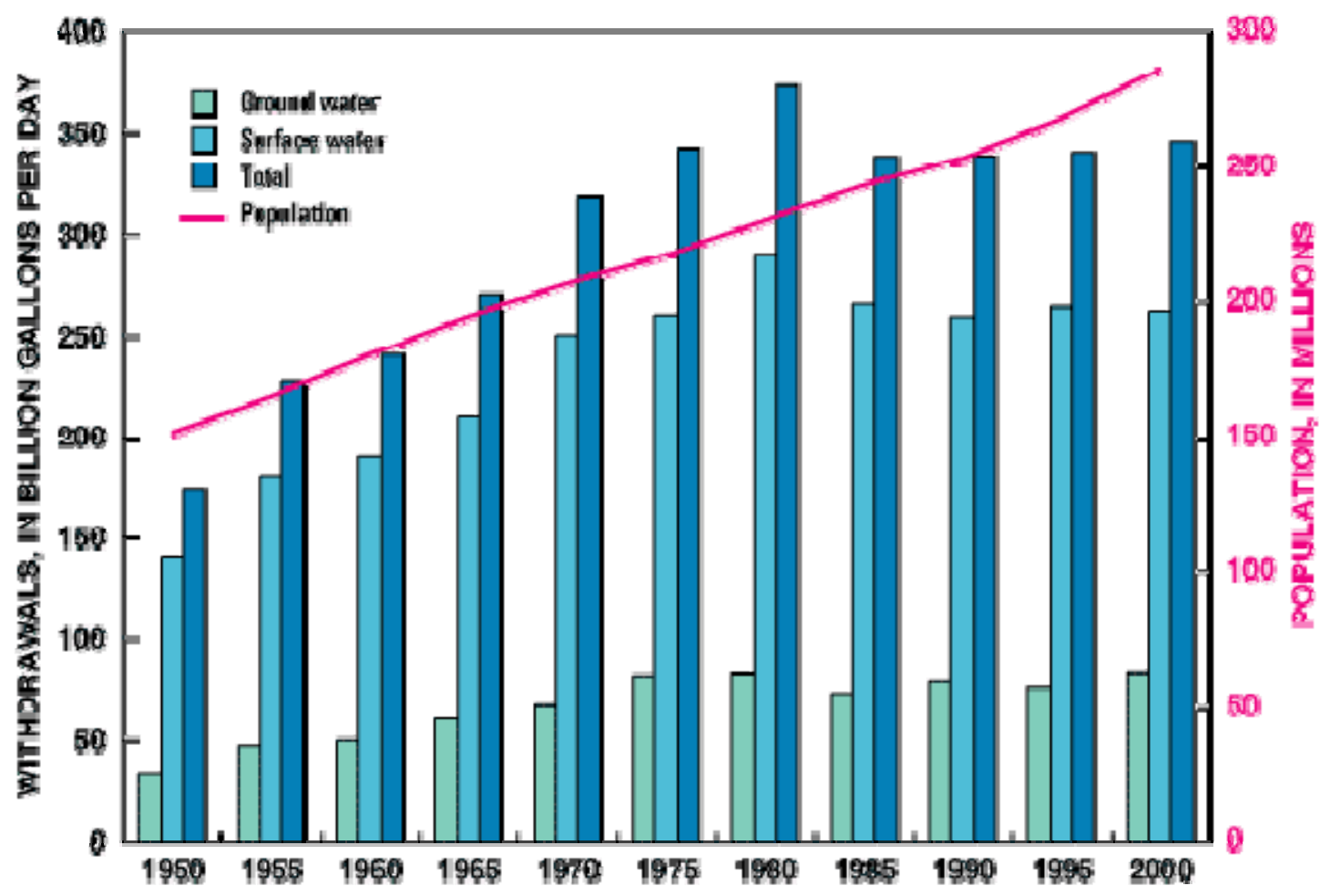

Figure 9 - Trends in U.S. freshwater withdrawals and population, 1950-2000 (Hutson et al., 2004)

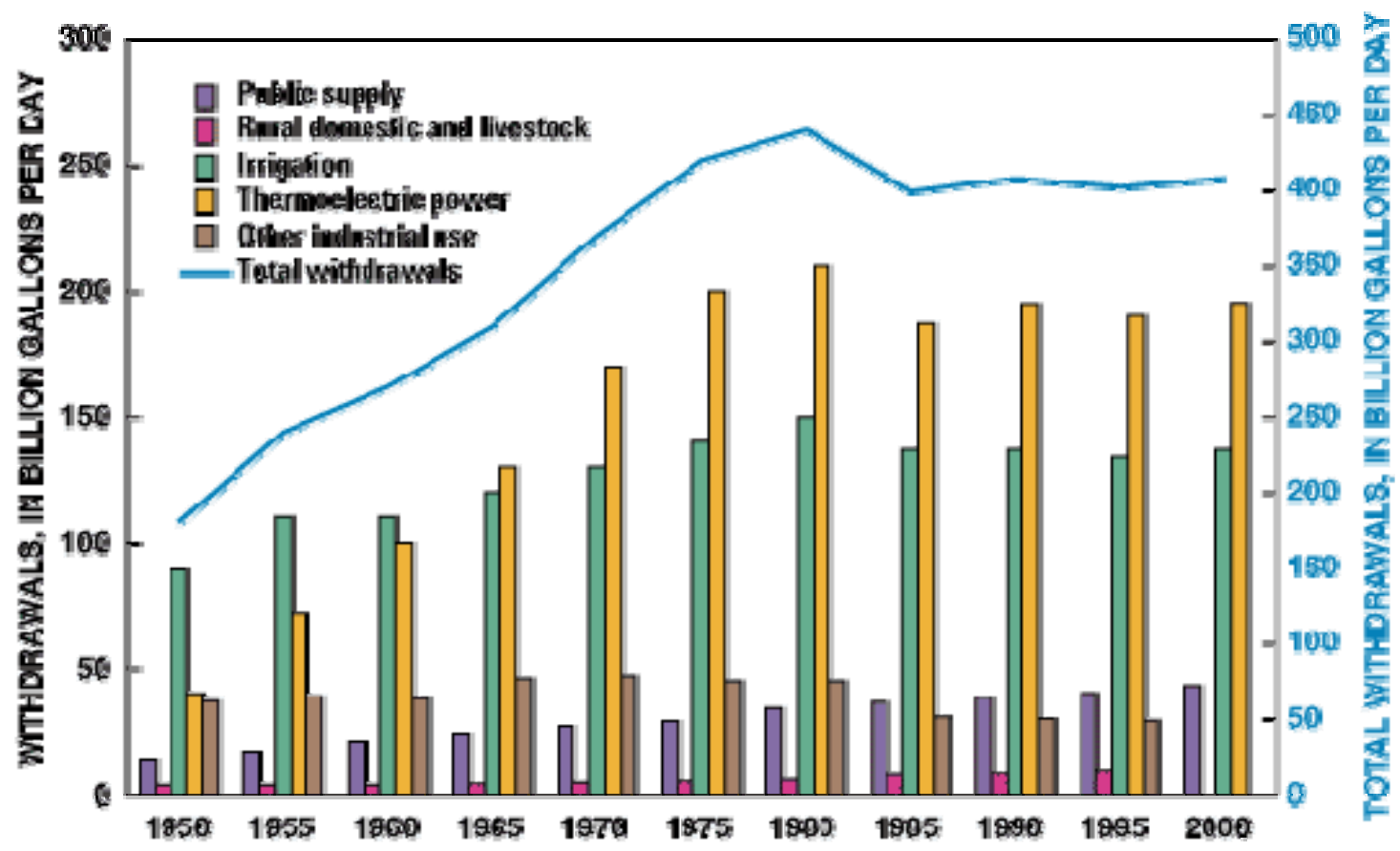

Figure 10 - Trends in total U.S. water withdrawals by water-use category, 19502000 (Hutson et al., 2004) 


\section{(7) Aquatic / Wetland Species at Risk}

This indicator (Figure 11) has not appeared before, either in the 2005 report or in earlier papers in this series. This data provides information about the presence of species at risk in a given watershed. The State agency-based Natural Heritage Network and The Nature Conservancy (TNC) assess the conservation status of plants and animals, and map out the population occurrences of those species at greatest risk of extinction. This indicator represents the number of aquatic or wetland-dependent species documented in a watershed that are classified by the Heritage Network as critically imperiled (identified by TNC as G1), imperiled (G2), or vulnerable (G3), or that are listed under the federal Endangered Species Act (ESA) as threatened or endangered.

The presence of rare or endangered species in a watershed is not necessarily an indication of poor watershed conditions. Indeed, it more likely indicates the opposite: in many instances these species persist only in areas of exceptionally high quality habitat. The presence of species at risk in a watershed indicates, however, that these watersheds are especially vulnerable to future water quality or habitat degradation, which could jeopardize the maintenance or recovery of these organisms. Watersheds considered vulnerable because of the presence of species at risk may require special attention to protect or restore water quality in order to maintain these biological values.

Figure 11 shows that in 403 watersheds, one species is known to be at risk; in 745 watersheds, 2 to 5 species are at risk; and, in 422 watersheds, more than 5 species are known to be at risk. There are some caveats about the data, however. Aquatic inventory efforts and data processing backlogs vary from state to state. Thus while available data is comparable, level of data completeness is inconsistent. Heritage species occurrence data are not based on comprehensive inventories of each watershed and major inventory gaps remain, especially for aquatic species. For this reason, some watersheds may actually have more species at risk than indicated. Similarly, lack of data for a watershed cannot be construed to mean that no species at risk are present. It is not currently possible using this data set to distinguish between lack of inventory data for a watershed and the absence of species at risk in that watershed.

Thanks are due to the State Natural Heritage Data Centers, The Nature Conservancy, and EPA for compiling and analyzing these data. 


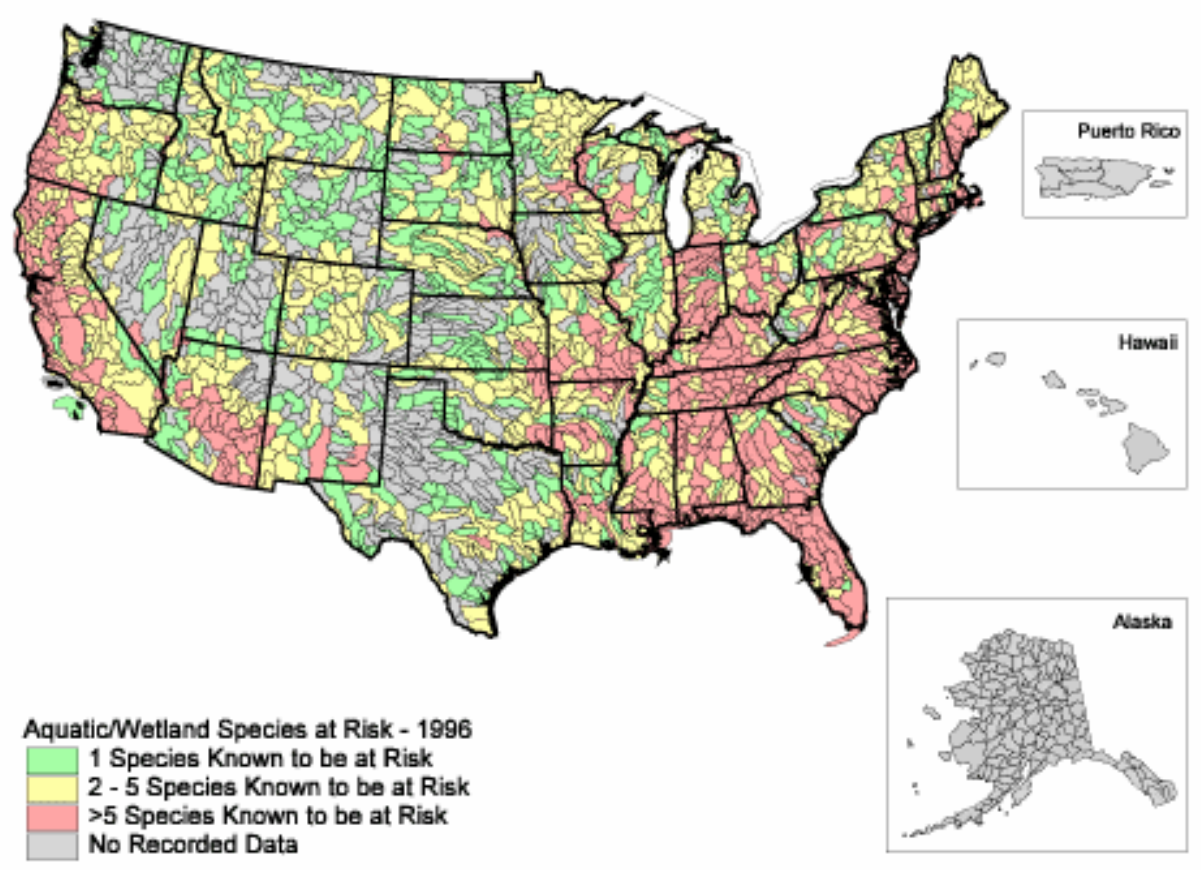

Figure 11 - Aquatic/Wetland Species at Risk, 1996

(Source: http://oaspub.epa.gov/eims/direntrpt.report?p_deid=1750\&p_chk=5582)

\section{(8) Agricultural Runoff for Soil, Pesticides, and Nitrogen}

Figure 12 has appeared before in both the 2005 SWRR report and earlier papers in this series. But, we have now elevated it from sub-indicator to full indicator status. This is principally because of its direct connection between land used for agriculture and such recognized water impacts as soil, pesticide, and nitrogen runoff.

The map shows that 526 watersheds have a low level of potential impact; 1055 watersheds have a moderate level; and, 529 have a high level of potential impact. A composite index was constructed to show which watersheds had the greatest potential for possible water quality problems from combinations of pesticides, nitrogen, and sediment. Watersheds with the highest composite score have a greater risk of water quality impairment from agricultural sources than watersheds with low scores. Watersheds could be ranked high because of a very high ranking of a single component, or moderately high rankings from two or more components. 
The composite indicator primarily represents sources of pollutants from cropland. It does not include any components for rangeland, pastureland, or privately managed forest land. This composite map combines three disparate agricultural vulnerability indicators -- pesticide runoff, nitrogen runoff, and in-stream sediment loads.

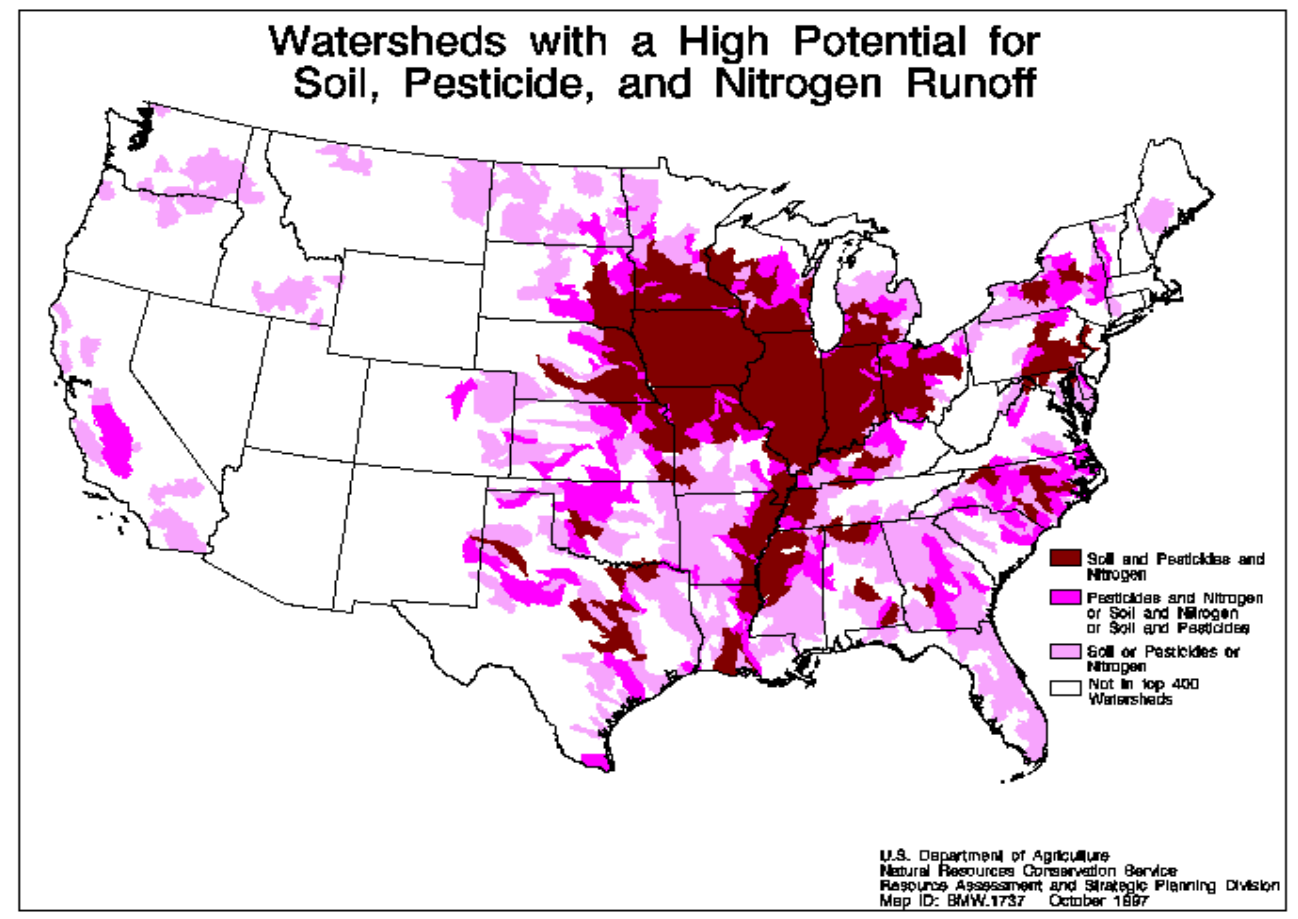

Figure 12 - Watersheds with a High Potential for Soil, Pesticide, and Nitrogen

Runoff, 1990-1995 (Source: http://www.nrcs.usda.gov/technical/land/lgif/m1737l.gif) 


\section{CONCLUSIONS}

The journey toward Sustainable Water Resources Management begins by determining the most important water issues and indicators. Sustainable Water Resources Roundtable participants are committed to interdisciplinary, inter-jurisdictional, and cross-ownership collaboration that identifies and supports national, state, and field-level activities to sustain water resources. The long-term goals of SWRR include the development of principles, criteria and indicators to support decision-making and identification of opportunities for collaboration on research needs.

Several ongoing initiatives by SWRR include:

- Continue to refine investigations into water indicators, especially which indicators can best support the efforts of other organizations doing related work, such as the Heinz Center or the other Roundtables. Work with federal and state agencies to determine how to best facilitate the missions of those agencies which have important policy responsibilities under public law.

- Recruit representatives from additional water interests, such as environmental groups, the business community, and Western water management agencies

- Continue work to establish and maintain relationships with the scientific community, to help build on the best ideas and practices in the water discipline. Encourage research into the nature of sustainability as it relates to water resources

- Leverage efforts by continuing an aggressive outreach program with the professional water resources community.

The sustainable solutions to water resources problems can be found if people thoroughly understand the issues and how each aspect of the society contributes to them 


\section{REFERENCES}

Alley, W.M. (2002). Some reflections on the sustainability of water resources: in Gerhard, L.C., Leahy, P.P., and Yannocone, V.J., Jr., Sustainability of energy and water through the $21^{\text {st }}$ century - Proceedings of the Arbor Day Farm Conference, October 8-11, 2000: Kansas Geological Survey Special Publication, 81-87

General Accounting Office (GAO) (2004). Environmental Indicators: Better Coordination Is Needed to Develop Environmental Indicator Sets That Inform Decisions, Report GAO-05-52, http://www.gao.gov/new.items/d0552.pdf

H. John Heinz III Center for Science, Economics and the Environment (2002). The State of the Nation's Ecosystems, Cambridge University Press

Hutson, S.S., Barber, N.L., Kenny, J.F., Linsey, K.S., Lumia, D.S., and Maupin, M.A. (2004). Estimated use of water in the United States in 2000, U.S. Geological Survey Circular 1268, 46p

Intergovernmental Panel on Climate Change (IPCC) (2001). Climate Change 2001: The Scientific Basis. Contribution of Working Group I to the Third Assessment Report of the Intergovermental Panel on Climate Change, World Meteorological Organization/United Nations Environment Programme, J.T. Houghton, Y. Ding, D.J. Griggs, M. Noguer, P.J. van der Linden, X. Dai, K. Maskell, and C.A. Johnson, Eds. Cambridge University Press, Cambridge, United Kingdom and New York, NY, USA, 881pp.

Intergovernmental Panel on Climate Change (IPCC) (2007). Climate Change 2007, http://www.ipcc.ch/

Karl, T.R, R.W. Knight, D.R. Easterling, R.G. Quayle (1996). Indices of Climate Change for the United States. Bull. Amer. Meteor. Soc., 77, 279-292.

Lane, M.E., Kirshen, P.H., and Vogel, R.M. (1999). Indicators of impacts of global climate change on U.S. water resources, Journal of Water Resources Planning and Management, 125(4): 194-204

National Research Council (NRC) (1992). Policy Implications of Greenhouse Warming: Mitigation, Adaptation, and the Science Base. National Academy Press, 918pp.

Smith, E. T. and Zhang, H. X. (2004). How Do We Know It's Sustainable? Measuring Water Sustainability Effectively is Challenging, Water Environment and Technology, June 2004, 37-41, http://acwi.gov/swrr/Rpt_Pubs/index.html

Smith, E. T. and Zhang, H. X. (2004a). Formulating Key Water Quality Indicators for Sustainable Water Resources Development, WEFTEC’04, October 2-6, New Orleans, LA, http://acwi.gov/swrr/Rpt_Pubs/index.html 
Smith, E. T. and Zhang, H. X (2005). Formulating Key Indicators for Sustainable Water Resources Development Part II: Scale Issue and Geographic Patterns, WEFTEC'05, October 29 - November 2, Washington, D.C., http://acwi.gov/swrr/Rpt_Pubs/index.html

Smith, E. T. and Zhang, H. X. (2006). Our Journey Towards Sustainable Water Resources Management: Preliminary Report by Sustainable Water Resources Roundtable, WEFTEC'06, October 21-25, Dallas, TX.

Smith, E. T. and Zhang, H. X. (2007). Taking the Long View: The journey toward sustainable water resources management begins by determining the most important water issues and indicators, Water Environment \& Technology, June 2007, 63-70.

Sustainable Water Resources Roundtable (SWRR) (2005). Preliminary Report, September 30, 2005, http://acwi.gov/swrr/Rpt_Pubs/prelim_rpt/index.html

Solley, W.B., Pierce, R.R., and Perlman, H.A. (1998). Estimated use of water in the United States in 1995: U.S. Geological Survey Circular 1200, 71p.

U.S. Department of Agriculture (2000). Summary Report: 1997 National Resources Inventory (Revised December 2000), USDA Natural Resources Conservation Service, Washington, D.C.

USEPA (2003). Draft Report on the Environment - Technical Document. Report EPA 600-R-03-050, US EPA Office of Research and Development and the Office of Environmental Regulation, http://www.epa.gov/indicators/index.htm; Science Advisory Board Comments on ROE: http://www.epa.gov/sab/pdf/sab_05_004.pdf

U.S. Geological Survey (1984). National water summary 1983 - Hydrologic events and issues, U.S. Geological Survey Water-Supply Paper 2250

U.S. Geological Survey (2004). Estimated use of water in the United States county-level data for 2000, http://water.usgs.gov/watuse/data/2000/index.html

Vorosmarty, C.J., Green, Pamela, Salisbury, Joseph, and Lammers, R.B. (2000). Global water resources - vulnerability from climate change and population growth, Science, 289: $284-288$

World Resources Institute (WRI) (2004). The World Resources Institute Earth Trends Report, Capture by Species: Fresh water Fish, http://earthtrends.wri.org/searchable_db and http://www.fao.org/fi/statist/FISOFT/FISHPLUS.asp 